Ann. Biol. anim. Bioch. Biophys., 1965, 5 (2), 317-320.

NOTE

\title{
EFFET LIÉ AU GÈNE C DE COLORATION DU PLUMAGE DE LA POULE DOMESTIQUE SUR LA CROISSANCE EN POIDS
}

\author{
P. MÉRAT, \\ avec la collaboration technique de G. CoQUeRei.le \\ Station de Recherches avicoles, \\ Centre national de Recherches zootechniques, Jouy-en-Josas (Seine-et-Oise)
}

Sur Io générations d'une population maintenue en ségrégation au locus $\mathrm{C}$ (présence/absence de pigments mélaniques dans le plumage), le poids à l'âge de 8 semaines a été comparé par la méthode des couples pour les animaux colorés (Cc ou $\mathrm{CC}$ ) $\epsilon$ t blancs $(\mathrm{cc})$. Les deux individus de chaque couple étaient du même sexe, frères ou sœurs, nés à la même date et élevés ensemble.

Les conditions d'élevage sont celles décrites en résumé auparavant (MÉRAT, I962). Les accouplements étaient pedigree, chaque poule étant accouplée à un seul coq.

Le tableau suivant donne les poids moyens par sexe et suivant le type de croisement relativement au locus $\mathrm{C}$ (tabl. I).

Dans les deux sexes, on constate donc au total un poids supérieur des animaux colorés, mais ceci est sensiblement plus marqué chez les poulcttes, où la différence est hautement significative.

La signification de cette différence n'était pas apparue sur des donnée plus restreintes de la même population (MÉRAT, I962). Le résultat présent apparaît en accord avec ceux de Jerome et Huntsmax (I959), de Smith et Fox (I96r, I963).

Les variances intra-années ne diffèrent pas significativement pour les deux types de plumage, comme l'indique le tableau 2.

Par ailleurs, la mortalité embryonnaire des derniers stades ne diffère pas sensiblement pour les animaux blancs et pour les colorés (données non publiées); pour la mortalité des jeunes de l'éclosion à 8 semaines d'âge, elle semble légèrement plus grande chez les poussins blancs, quoique la différence ne soit pas significative. De toute façon, ceci ne suggère pas la possibilité d'une élimination sélective de poussins à mauvaise croissance parmi les colorés. 

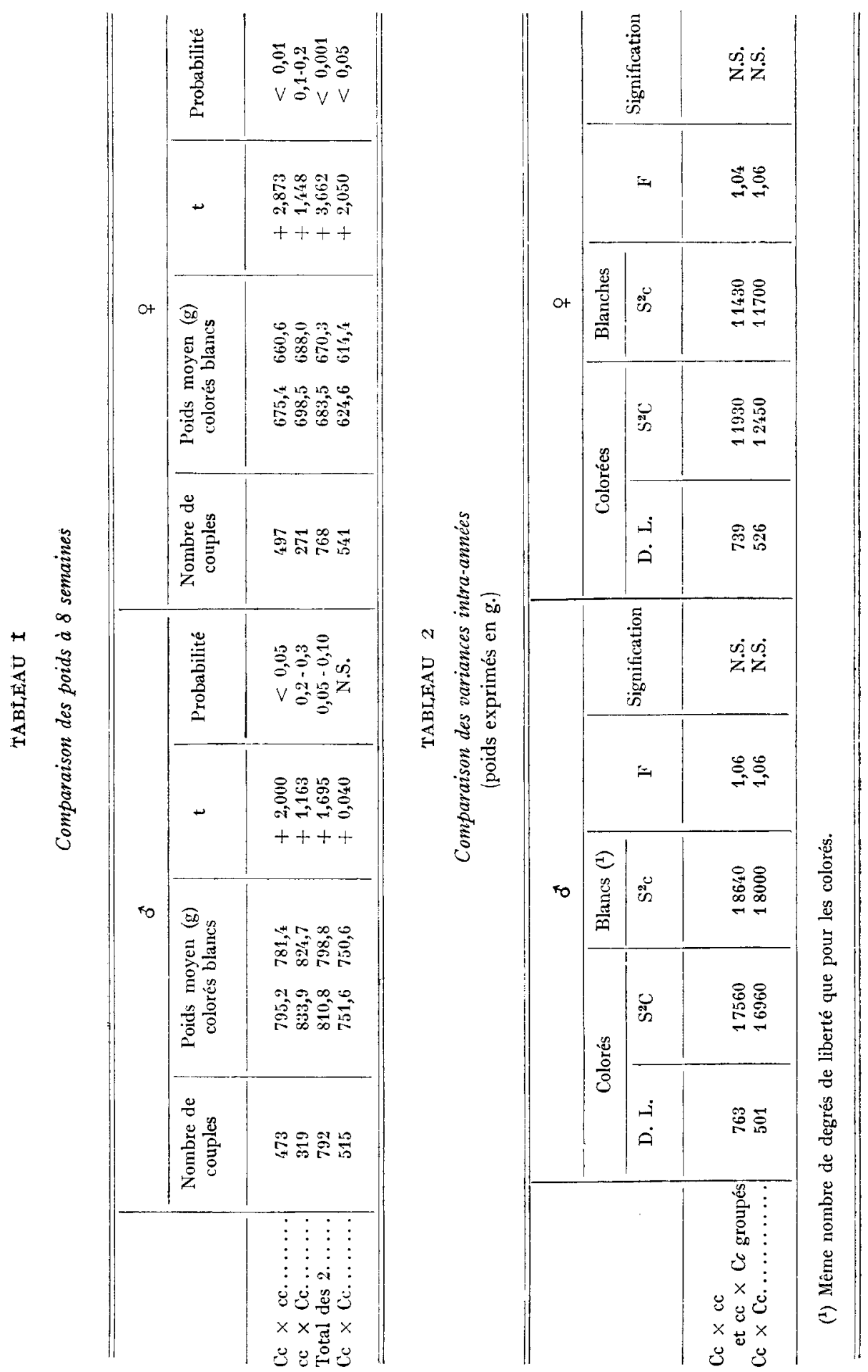


\section{SUMMARY}

EFFECT ON GROWTH ASSOCIATED WITH THE C PLUMAGE COLOUR GENE IN THE FOWL.

Over ten generations of a strain segregating at the $\mathrm{C}$ locus, coloured chicks were compared for 8-week weight with recessive white ones, the comparison being restricted to pairs of full sibs of the same hatch. In both sexes, but more so in females, $\mathrm{CC}$ or $\mathrm{Cc}$ chicks were heavier than cc ones.

\section{RÉFÉRENCES BIBLIOGRAPHIQUES}

Jerome F. N., Huntsman C. M., I959. A comparison of the growth rate of colored and recessive white chicks. Poull. Sci., 38, 238-239.

MÉrat P., I962. Quelques relations entre caractères extérieurs à hérédité simple et productivité chez les volailles. C. R. XII Congr. Mond. Avic., II, p. $71-76$.

Sмyтh J. jr., Fox T. W., I96r. The effect of recessive white on growth rate in the fowl. Poult. Sci., 40, $810-8 \mathrm{II}$.

Sмyтh J. jr., Fox T. W., 1963. The effect of $\mathrm{CC}, \mathrm{Cc}$ and $\mathrm{Cc}$ plumage color genotype on body weight in the fowl. Poult. Sci., 42. I $44 \mathrm{I} \cdot \mathrm{I} 445$. 